\title{
O conjunto Jardim Ana Rosa e o Weissenhofsiedlung: aproximações
}

\author{
Sergio Luís Abrahão, Mirthes Ivany Soares Baffi*
}

Resumo Idealizado pelo Werkbund alemão, o conjunto Weissenhofsiedlung tornou-se um marco para a Nova Arquitetura e informou os debates que tiveram lugar nos primeiros Congressos Internacionais de Arquitetura Moderna. Por sua vez, o conjunto Jardim Ana Rosa, construído pelo Banco Hipotecário Lar Brasileiro, na cidade de São Paulo, tornou-se 30 anos depois da experiência alemã, um significativo exemplar de arquitetura moderna voltado para a classe média. Este trabalho tem como objetivo identificar e descrever os principais pontos de aderência existentes nas concepções e nos projetos arquitetônicos e urbanísticos dos citados conjuntos.

Palavras-chave: projetos urbanos, conjunto habitacional, arquitetura moderna.

\section{The Ana Rosa Garden and the Weissen- hofsiedlung: approximations}

\begin{abstract}
Idealized by the German Werkbund, the set of houses known as Weissenhofsiedlung, became a reference for the New Architecture and informed the debates that took place in the first International Congresses of Modern Architecture. The Jardim Ana Rosa, a residential complex built by Lar Brasileiro Bank, 30 years after the German experience, has become a significant example of modern architecture for the middle class. This work aims to identify and describe the main points of adhesion existing in the conceptions and the architectural and urbanistic design of thr mentioned sets.
\end{abstract}

Keywords: urban projects, housing, modern architecture.

\section{El conjunto Jardim Ana Rosa y el Weissen- hofsiedlung: aproximaciones}

Resumen Ideado por el Werkbund alemán, el conjunto Weissenhofsiedlung se convirtió en un marco para la Nueva Arquitectura e informó los debates que tuvieron lugar en los primeros Congresos Internacionales de Arquitectura Moderna. El Jardín Ana Rosa, construido por el Banco Lar Brasileiro, en la ciudad de São Paulo, se convirtió, 30 años después de la experiencia alemana, un ejemplo significativo de arquitectura moderna orientada a la clase media. Este trabajo tiene como objetivo identificar y describir los principales puntos de adherencia existentes en las concepciones y en los proyectos arquitectónicos y urbanísticos de los citados conjuntos.

Palabras clave: proyectos urbanos, conjunto habitacional, arquitectura moderna. 
* Sergio Luís Abrahão é Arquiteto e Urbanista, professor do curso de graduação de Arquitetura e Urbanismo da Universidade Paulista de São Paulo - UNIP, ORCID <https://orcid.org/00000001-5181-2613>; Mirthes Ivany Soares Baffi é Arquiteta e Urbanista, arquiteta restauradora do Departamento de Patrimônio Histórico da cidade de São Paulo, ORCID <https://orcid.org/00000001-8987-0333>.

10 Banco Hipotecário Lar Brasileiro foi responsável, no período ... continua na próxima página... presente trabalho é resultado de uma investigação, que teve como objetivo identificar e descrever os principais pontos de aderência existentes nas concepções e nos projetos arquitetônicos e urbanísticos dos conjuntos de moradias Jardim Ana Rosa, construído por um banco imobiliário, o Banco Hipotecário Lar Brasileiro ${ }^{1}$, na cidade de São Paulo, entre 1940 e 1950 e o Weissenhofsiedlung construído em 1927, a partir de uma articulação bem sucedida entre o Werkbunder Alemão², uma influente associação de arquitetos, artesões, industriais, escritores e outros profissionais, com o Departamento de Obra Publicas da Cidade de Stuttgart.

Foram três as motivações que levaram à realização desta investigação. A primeira, pelas qualidades arquitetônicas e urbanísticas do conjunto de moradias que constituem o Weissenhofsiedlung, que mesmo desfalcado de 10 residências destruídas pelo bombardeio nazista de 1944, foi declarado, em 1958, monumento cultural da cidade de Stuttgart, bem como pela influência que viria a exercer em diversas realizações semelhantes ocorridas posteriormente na Alemanha e na Europa (Eskinazi, 2009). A importância fundamental que tal conjunto representa para a história da arquitetura moderna, está amplamente espelhada em publicações internacionais e no próprio acervo existente no Museu do Weissenhof, sediado em uma das casas de Le Corbusier e Pierre Jeanneret.

A segunda pelas inquestionáveis qualidades arquitetônicas e urbanísticas do Conjunto Jardim Ana Rosa, que em 2013, seria reconhecido pelo Conselho Municipal de Preservação do Patrimônio Histórico Cultural e Ambiental da Cidade de São Paulo - CONPRESP, como um bem a ser preservado para a memória da cidade ${ }^{3}$, como também pela sua relevância para a memória da arquitetura moderna paulistana, como já apontavam as revistas de arquitetura do período.

De fato, o Conjunto Jardim Ana Rosa tem sido referenciado tanto em trabalhos publicados sobre as obras do arquiteto envolvidos, quanto sobre as realizações do Banco Lar Brasileiro (Bedolini, 2014), em estudos comparativos entre obras de arquitetura moderna (Abascal e Pimenta, 2009. Barbara, 2004), dentre outros. Em comum, tais publicações evidenciam o caráter moderno do conjunto Jardim Ana Rosa e as trajetórias profissionais dos arquitetos nele envolvidos.

A terceira motivação, ou seja, a aproximação das duas experiências, foi enriquecida pela leitura de trabalhos que levantam a hipótese da influência do Weissenhofsiedlung na concepção arquitetônica e urbanística do Conjunto Jardim Ana Rosa. Bedolini (2014, p.36), identifica o período da construção dos conjuntos do Banco Lar Brasileiro, como aquele em que a plena correspondência entre forma, função e estrutura na produção de moradias coletivas, presentes nas obras do Weissenhofsiedlung e que foram debatidas no $2^{\circ}$ e $3^{\circ}$ encontros do CIAM, seriam assumidas como fenômeno intelectual entre os arquitetos brasileiros. A seu ver, esse fato teria contribuído para enfraquecer a resistência, até então existente, de se associar verticalização à moradia 
.. continuação da nota 1 ...

de 1935 a 1965, pela produção no Estado de São Paulo de 11 conjuntos de residências unifamiliares, 11 edifícios de apartamentos e 09 edifícios de uso misto, perfazendo um total de 31 conjuntos com 1812 unidades residenciais. Com a crise inflacionária a partir dos anos 60 e as mudanças estruturais no sistema de financiamento para a casa própria implantadas em 1964, o Banco Hipotecário Lar Brasileiro deixa de financiar moradias e se transforma em banco comercial.

2 A Deutscher Werkbund foi, segundo Leonardo Benévolo (1976, p.376), a mais importante organização cultural alemã anterior a $1^{\text {a }}$ Guerra Mundial. Fundada em 1907, em Munique, era composta por arquitetos, artesões, industriais, escritores e outros profissionais preocupados, de uma maneira geral, com a qualidade na produção do design alemão, da arquitetura, das cidades, diante da realidade dos novos tempos dominados pelo avanço da industrialização em todos os setores da produção e "de 'educar' a população com estes 'objetos' bem concebidos" segundo informações do catálogo da exposição do Deutscher Werkbund, realizada em 2014 no Centro Cultural São Paulo. Dentre seus fundadores incluíam-se Peter Behrens, Joseph Maria Olbrich, Theodor Fischer, Josef Hoffmann e Fritz Schumacher, considerados, "os pioneiros de uma arquitetura que admite a modernidade industrial, aceitando na integra a geometria, a impessoalidade e a normalização da produção fabril." (Schwartz, 2014, p.09).

3 Resolução n 37/CONPRESP/ 2013. Disponível em <http:// www.prefeitura.sp.gov.br/cidade/secretarias/cultura/participacao_social/conselhos_e_orgaos_colegiados/conpresp/index. php?p=13862> coletiva. Por outro lado Fernanda Barbara (2004), ao estudar as tipologias habitacionais do conjunto Jardim Ana Rosa e do Edifício Copan, argumenta que o desenho do loteamento e a forma de organização e soluções projetuais adotadas no conjunto Jardim Ana Rosa, indicam ter como precedência o Weissenhofsiedlung.

A possível relação, indireta em Bedolini e direta em Fernanda Barbara, entre as duas experiências, norteou a investigação no sentido de se verificar uma similaridade entre elas e observar o que a experiência do Conjunto Ana Rosa trazia da pioneira experiência do Weissenhofsiedlung, mesmo considerando a ocorrência e as possíveis influências de outras experiências europeias posteriores a esta última e os frequentes debates e reflexões que alimentaram a arquitetura e o urbanismo modernos depois da construção do Weissenhofsiedlung.

A pesquisa constituiu-se de consultas tanto em fontes bibliográficas afins, quanto em documentos pertencentes à instituições brasileiras - com destaque para o Departamento de Patrimônio Histórico da Cidade de São Paulo - e alemãs - como o Museu Weissenhof em Stuttgart - bem como visitas de campo em ambos os locais, cujos resultados, devidamente sistematizados, constam das seções que se seguem.

A Seção 1 descreve a concepção e o sistema de organização e construção do Weissenhofsiedlung, as principais ideias que nortearam tal experiência e destaca o reconhecimento de seu caráter pioneiro e sua relevância para a arquitetura e urbanismo modernos, em especial a influência de seus idealizadores, na organização do I Congresso Internacional de Arquitetura Moderna - CIAM, cujas recomendações seriam literalmente transcritas e divulgadas no catálogo do I Salão de Arquitetura Tropical, realizado no Rio de Janeiro em 1935. Este evento contava entre seus organizadores com o então jovem arquiteto Abelardo de Souza, que alguns anos depois seria o responsável pela concepção urbanística do Conjunto Jardim Ana Rosa e agruparia em seu entorno uma série de arquitetos identificados com o movimento moderno na arquitetura.

A Seção 2 descreve a concepção e o sistema de organização para o projeto e construção do Conjunto Jardim Ana Rosa, aponta suas principais ideias norteadoras, bem como descreve o partido adotado no parcelamento da área e sua relação com a topografia existente; identifica os arquitetos envolvidos; as soluções projetuais dos edifícios e peculiaridades de implantação. Foi dado destaque aos prédios Guapíra e Hicatú projetados pelo arquiteto Kneese de Mello e os conjuntos Gregório Serrão e Gaspar Lourenço projetados pelo arquiteto Salvador Candia, pelo diálogo que esses prédios estabelecem entre si.

As Considerações finais, apresentam os resultados das análises realizadas do Weissenhofsiedlung e do Conjunto Jardim Ana Rosa, no sentido de se identificar o que de comum cada uma dessas experiências apresenta em seus aspectos relativos à concepção geral, às características de implantação, a relação com o tecido urbano existente e às soluções arquitetônicas adotadas.

Em apartado, estamos apresentando após as Considerações Finais, verbetes sobre os arquitetos Victor Bourgeois e de Bruno Taut pelas peculiaridades de suas participações na execução do Weissenhofsedlung, de Salvador Candia e Eduardo Kneese de Melo pelo destaque dado às suas obras nas descrições do Conjunto Jardim Ana Rosa. 


\section{Seção 1 - A exposição “Die Wohnung"}

4 Segundo levantamento realizado por Eskinazi (2009), as principais exposições de arquitetura realizadas na Alemanha anteriormente à Die Wohnung (1927) foram: a Exposição "Ein Dokument Deutscher Kunst" na cidade de Darmstadt em 1901, em que se construiu um quarteirão moderno integrando moradia e trabalho; a "Algemeine Städtebau-Aussetellung" (Exposição Geral de Urbanismo) em 1910, na cidade de Berlim, em que se apresentou ao público os resultados de um concurso realizado em 1909 para o desenvolvimento urbano daquela cidade; a "Deutsche Werkbund Ausstellung", em 1914, na cidade de Colônia, para mostrar a rica variedade de manifestações protomodernistas na Alemanha e aprofundar o debate em torno das questões conceituais subjacentes aos primórdios do movimento moderno. Após a exposição de 1927, Eskinazi (2009) destaca, no âmbito do movimento moderno, a Deutsche Bauasstellung, realizada em um enorme pavilhão na cidade de Berlim em 1931, que apresentava fragmentos, em escala real, de edifícios de apartamentos, com o objetivo de debater a habitação econômica e construção em massa; e em 1957 a Interbau, na cidade de Berlim, com o intuito de se mostrar o que de melhor a arquitetura e o urbanismo moderno ofereciam através da reconfiguração da Hansaviertel, uma urbanização no coração de Berlim que havia sido destruída pelos bombardeios, durante a segunda guerra.

5 CABRAL, Cláudia Piantá Costa. Do Weissenhofsiedlung ao Hansaviertel. A arquitetura moderna e a cidade pensadas desde a habitação. Resenhas Online, São Paulo, ano 10, no 117.02, Vitruvius, set. 2011. <http://www.vitruvius. com.br/revistas/read/resenhasonline/10.117/4025>.

$6<$ http://www.weissenhof2002. de/english/weissenhof.html>.

7 Catalogo da Exposição Deutscher Werkbund: 100 anos de arquitetura e design na Alemanha. São Paulo: Centro Cultural São Paulo, 2014, p,36
A origem do Weissenhofsiedlung tem lugar, em março de 1925, na cidade alemã de Berlim, durante uma reunião geral do Werkbund, em que um dos seus grupos de trabalho - o Württemberg Working Group of Deutscher Werkbund - propôs a realização, na cidade de Stuttgart, de uma exposição de moradias, com o intuito de disseminar os conceitos que vinham sendo gestados pelo Deutscher Werkbund em torno das questões que envolviam a forma mais adequada de se morar naqueles tempos de consolidação de uma sociedade marcada pela industrialização. Em termos conjunturais, a cidade de Stuttgart, impulsionada pelo crescimento de seu parque industrial, vivia excelente fase econômica e assistia ao aumento de seu contingente populacional, cuja consequência imediata traduzia-se na pressão crescente por novas moradias e por melhores condições de vida.

A exposição proposta, que viria a ser nomeada "Die Wohnung" ("A Moradia"), não se restringia à simples mostra de projetos arquitetônicos; compreendia sobretudo mostrar as moradias devidamente edificadas e equipadas. Diferentemente das exposições de arquitetura e urbanismo havidas anteriormente na Alemanha", a "Die Wohnung" buscava expor um conjunto de moradias que espelhasse, conforme observou Eskinazi (2009, p.10) "a elaboração de ideias modernas em um programa de habitação coletiva e social", ou complementando com Cabral (2011), o de expor:

"Um bairro modelo onde se poderia demonstrar 'in loco' as possibilidades da nova arquitetura (...) oferecendo ao público um novo conceito de morar, cuja manifestação estendia-se do desenho de interiores às relações entre arquitetura e cidade, do emprego de materiais industrializado recentes às inovações de sistemas construtivos" ${ }^{5}$.

Apresentada ao Departamento de Obras Públicas da Cidade de Stuttgart, a proposta da exposição foi recebida com entusiasmo, sobretudo pela visibilidade e atenções que poderia atrair para a cidade, levando a municipalidade a dar apoio político e material, para sua viabilização: doou a gleba e assumiu os custos da implantação e das obras, além dos honorários dos arquitetos envolvidos ${ }^{6}$ - através dos recursos do programa municipal de construção da cidade de Stuttgart.

A estratégia do Werkbund alemão - uma entidade privada - em implantar um projeto urbano em parceria com o Departamento de Obras Públicas da cidade de Stuttgart - uma entidade pública - revela um aspecto bastante difundido nos discursos e nas práticas contemporâneas de intervenção em espaços urbanos, qual seja, o estabelecimento de parceria entre o poder público e entidades privadas como meio de se implantar e gerenciar projetos urbanos.

Para coordenar o projeto do bairro modelo foi escolhido o arquiteto Mies van der Rohe, então vinculado ao Werkbund alemão que, naquele mesmo ano de 1925, apresentaria ao Departamento de Obras Públicas da Cidade de Stuttgart seu primeiro plano para o conjunto de habitações a ser construído. Esta apresentação causou grande impacto, entre os integrantes do citado órgão municipal, sobretudo porque atendia algumas de suas expectativas, tais como, o caráter definitivo das moradias a serem expostas e a possibilidade da comercialização e ocupação imediatas dessas unidades, após o encerramento da exposição. Para o Werkbund, seria a oportunidade de "apresentar novas formas de habitar, como parte de uma 'luta' por novas formas de vida em uma nova época vindoura" ${ }^{7}$ 
Para o loteamento e implantação do conjunto a ser construído para a exposição foi destinada uma gleba de topografia descendente, no topo da colina de Weissenhof daí o conjunto ser conhecido como Weissenhofsiedlung - situada ao norte da cidade de Stuttgart, próximo ao seu centro histórico. O curto tempo disponível para viabilizar a exposição - de abril de 1925 a julho de 1927 - e as longas discussões havidas com o Departamento de Obras, na definição dos arquitetos a serem convidados a participar dos projetos das moradias, a partir das sugestões de Mies van der Rohe, contribuíram para que não fosse possível produzir moradias de baixo custo, de modo a permitir sua comercialização junto às camadas populares (Joedicke, 2016).

A exposição "Die Wohnung" não se resumiu apenas à mostra do conjunto de moradias construídas a partir de projetos autorais de arquitetos ligados ao Werkbund, mas também compreendeu, simultaneamente, outras 3, quais sejam:

- Uma mostra, em área vizinha ao bairro de Weissenhof, de novos métodos e materiais construtivos voltados à construção de novas edificações.

- Uma mostra, no centro de Stuttgart, de objetos de mobiliário, pisos, cozinhas funcionais e de novos aparelhos para facilitar e diminuir o tempo gasto na execução os trabalhos domésticos; e, finalmente.

- Uma mostra, que foi intitulada em tradução livre, Exposição internacional sobre Planos e Modelos da Nova Arquitetura, montada por Ludwig Hilberseimer, também no centro da cidade.

Inaugurada em 23 de julho de 1927, a exposição "Die Wohnung" recebeu até seu encerramento, em 31 de outubro de 1927, cerca de 500.000 visitantes e alcançou, segundo dados presentes na exposição permanente do Weissenhof Museum, projeção mundial.

\section{Weissenhofsiedlung: o bairro modelo}

Apesar dos percalços com o Departamento de Obras da cidade de Stuttgart a concepção geral de implantação prevista por Mies van der Rohe se manteve: mesclar habitações unifamiliares (isoladas ou em blocos) com habitações multifamiliares, em uma gleba de topografia acidentada, trabalhada em uma série de terraços articulados acompanhando o declive do terreno.

Também foi mantida a liberdade de ocupação dos lotes e a preferência por gabaritos baixos, de no máximo 4 pavimentos, a serem percebidos quando vistos em conjunto e implantados harmoniosamente de forma livre e não alinhados, ladeados por vegetação, porém seguindo primordialmente a orientação dada pela insolação e pelas vias de circulação para veículos e pedestres (Figura 1).

Com vias circundando todo o perímetro do conjunto, o acesso veicular ao seu interior se dá apenas por meio de duas ruas - a Pankokweg e a Bruchmannweg - que, no entanto, não foram concebidas para que os veículos cruzassem o terreno. Somente ao pedestre é dada esta condição, através da continuidade dessas vias por escadas que vencem a topografia acidentada (Figura 2). 

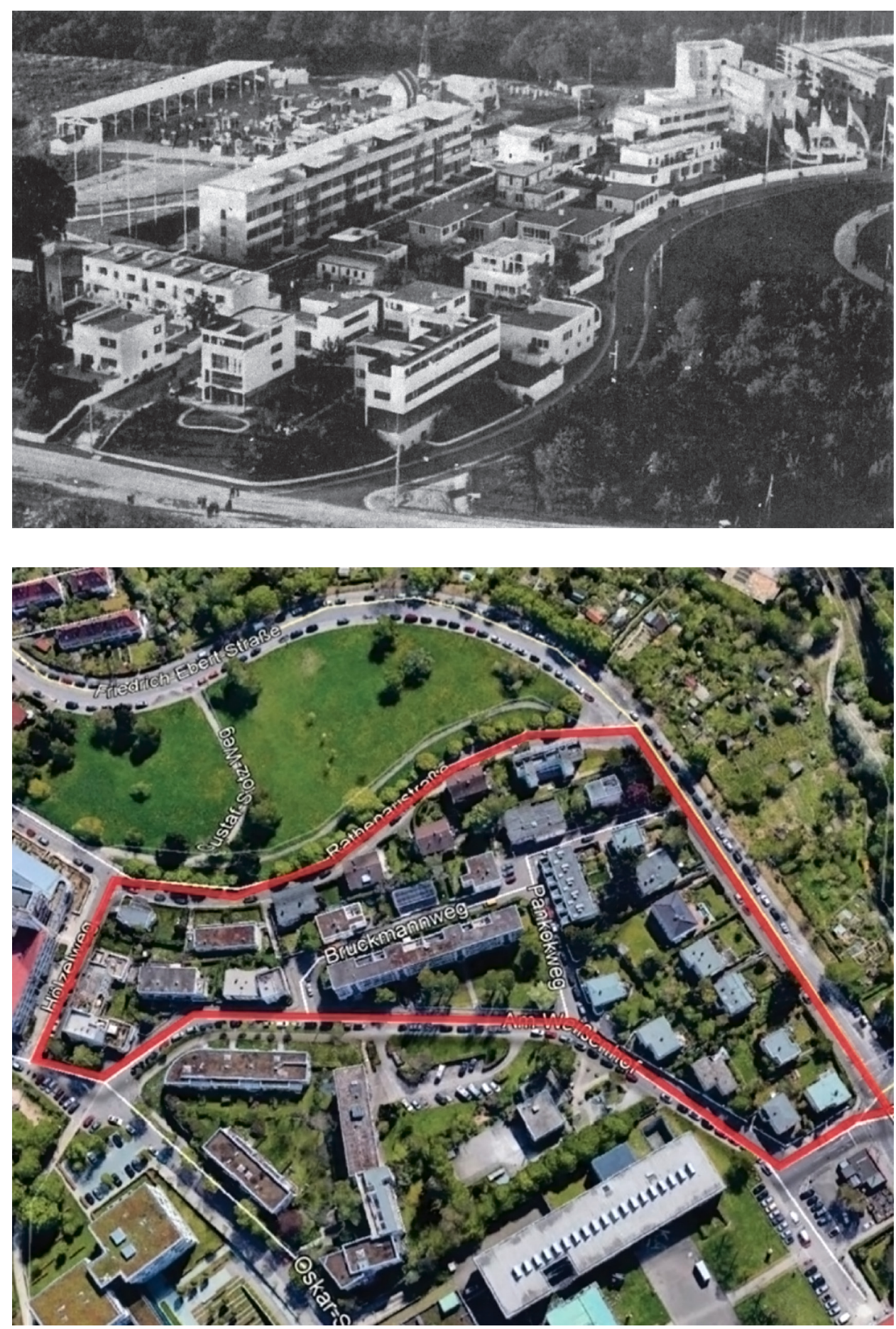

Figura 1 (topo): Vista geral sul do Weissenhofsiedlung, em 1927. Fonte: Joedicke, (2016, p.18).

Figura 2: Vista aérea do Weissenhofsiedlung, delimitado em vermelho. Fonte: Google Earth, Pro-demarcação realizada pelos autores, agosto 2017. 
Figura 3: Identificação dos autores do conjunto de edifícios que constituíam o Weissenhofsiedlung antes do bombardeio pelos nazistas. As indicações de edificações com hachuras representam as totalmente destruídas pelo citado bombardeio. Fonte: Display informativo instalado no Weissenhofsiedlung/ acervo dos autores (2016).
Outras características importantes espelhadas na implantação e nos aspectos construtivos dos edifícios do conjunto são: a continuidade espacial entre os espaços internos e externos :- os espaços internos se abrem para o exterior, porém se conservam distintos desses -; as soluções estruturais independentes das vedações; as fachadas de desenho flexível, mesmo admitindo a austeridade das formas cúbicas.

Em comum, os edifícios projetados por diferentes arquitetos e construídos ao mesmo tempo (Figura 3), procuraram espelhar, através de uma nova estética e do emprego de técnicas construtivas inovadoras, uma nova forma de habitar que respondesse à necessidade de uma nova atitude em relação à família, à prioridade do homem sobre a propriedade e as mudanças que começavam a se manifestar na vida comunitária (Joedicke, p.73).

\section{DIE WEISSENHOFSIEDLUNG}

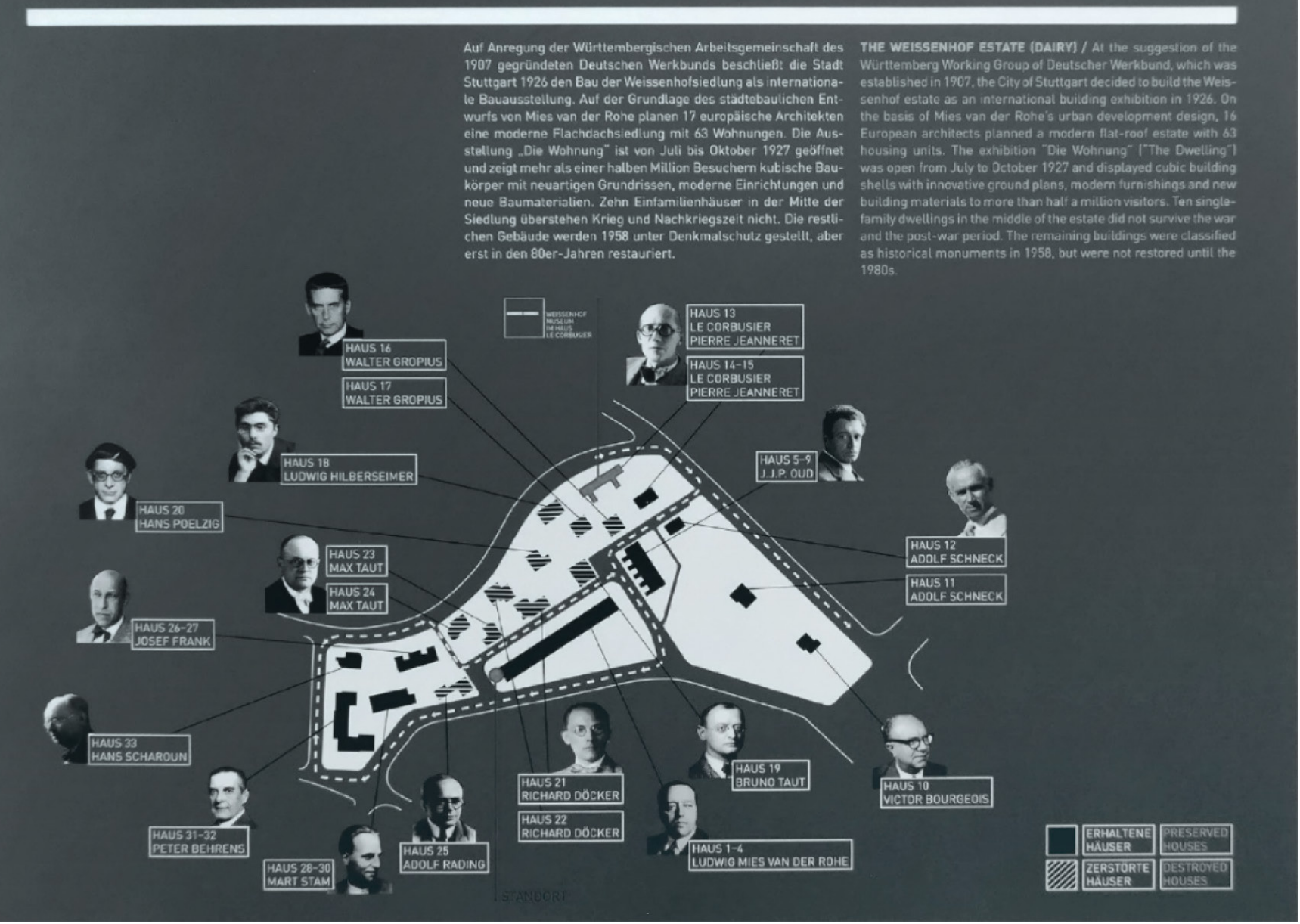




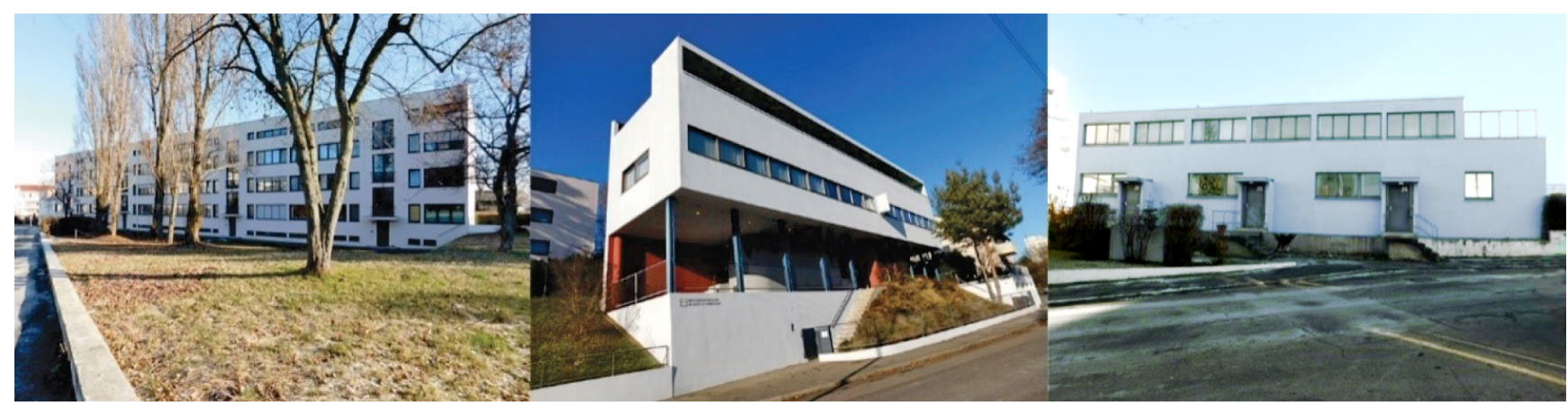

Figura 4: Três exemplares de edifícios que integram o Weissenhofsiedlung; da esquerda para direita: Edifício residencial de Ludwig Mies Van Der Rohe; As "Residências Gêmeas" de Le Corbusier e Pierre Jeanneret, atual Museu do Weissenhof e o conjunto unifamiliar constituído de três casas geminadas de Mart Stam. Fonte: acervo dos autores (2016).
Ao todo, foram produzidas 63 unidades de moradia distribuídas em 33 edifícios e residências unifamiliares. Os 17 arquitetos responsáveis por esta produção foram: Mies Van Der Rohe; J. J. P. Oud; Victor Bourgeois; Adolf G. Schneck; Le Corbusier/ Pierre Jeanneret; Walter Gropius; Ludwig Hilberseimer; Bruno Taut; Hans Poelzig; Richard Döcker; Max Taut; Adolf Rading; Josef Frank; Mart Stam; Peter Behrens; Hans Scharoun. Em 1944, 10 dessas casas seriam destruídas por um bombardeio nazista. Com o fim da guerra outras casas foram construídas na área bombardeada, sem guardar relação com as demais e novas construções foram anexadas àquelas que resistiram ao citado bombardeio. Em 1958, o Weissenhofsiedlung foi, pela qualidade urbanística e arquitetônica de seu conjunto classificado como monumento cultural da cidade de Stuttgart.

De fato, documento único dos arquitetos alemães representados no Weissenhofsiedlung, a publicação de 1927 "Bau und Wohnung" ("Construção e Moradia" em tradução livre), faz referência aos cinco elementos que Le Corbusier e Pierre Jeanneret apontavam como essenciais para a Nova Arquitetura, quais sejam: o emprego de pilotis, o uso de cobertura com terraços ou jardins; plantas livres nos pavimentos; janelas em fita e tratamento livre das fachadas, possibilitados pelo emprego de sistema estrutural independente.

Ainda que a maioria das construções do Weissenhofsiedlung não tenha lançado mão do emprego de pilotis (presentes nas "Residências Gêmeas", de Le Corbusier e Pierre Jeanneret), foram usuais o emprego de estruturas independentes e, consequentemente, o tratamento livre das fachadas, o emprego de janelas em fita e plantas livres como bem ilustra o edifício multifamiliar de Mies van der Rohe: um bloco com 24 apartamentos, variando de $44 \mathrm{~m}^{2}$ a $88 \mathrm{~m}^{2}$, estrutura em aço preenchido com alvenaria, cobertura com terraço e lavanderias comuns, janelas em tira e diferentes tipologias de apartamento em cada piso, em que a padronização e a racionalização são pontos de partida (Figura 4).

Pela primeira vez tais características estavam presentes num conjunto de edifícios projetados por diferentes arquitetos e construídos ao mesmo tempo e não em experiências projetuais isoladas. Como se pode verificar nos registros da "Bau und Wohnung", cada arquiteto teve a liberdade de formular e pôr em pratica sua visão 
do que seria esse novo tipo de construir para uma nova forma de viver e habitar, sem que isso comprometesse a unidade do conjunto, ao contrário, o resultado final exprime o incontestável valor e pioneirismo, que o Weissenhohsiedlung, na figura de seus idealizadores, representou para a disseminação dos princípios da arquitetura moderna da primeira metade do século XX.

Afinal, foi sob forte influência deste grupo que seria concebido e realizado, em 1928, no Castelo de La Sarraz, o I Congresso Internacional de Arquitetura Moderna - CIAM, através do qual buscavam disseminar a nova arquitetura que estava sendo desenvolvida na Europa dos anos 1920 e, desta forma, balançar o domínio do neoclassicismo nas academias de arquitetura. (Munford, 2002, p.09).

As recomendações do I CIAM, que ficaram internacionalmente conhecidas e difundidas como Declaração de La Sarraz, diziam respeito a um novo modo de pensar e produzir arquitetura e cidades. No tocante à arquitetura apregoavam vincular a arquitetura no sistema econômico geral; embasar a produção na racionalização e na padronização (tão caros para Mies van der Rohe); aplicar esforço mínimo de trabalho para a produção.

Com relação às cidades apregoavam a ordem funcional como essência da urbanização; que tal ordem deveria seguir três funções principais: a moradia, a produção e o descanso; e que essas três funções deveriam se apoiar em uma nova divisão do solo, na organização do trafego e na legislação.

No tocante a divisão do solo, propunham a adoção de uma política de terras coletiva, de modo a evitar a compra e venda e a especulação de imóveis diagnosticada como responsáveis pela divisão caótica de terras nas cidades.

O alcance das recomendações que constituem a Declaração de La Sarraz, atravessou fronteiras. No Brasil, por exemplo, seria transcrita no catálogo do I Salão de Arquitetura Tropical, realizado em 1933, na cidade do Rio de Janeiro, com o objetivo de "marcar o início da racionalização da arte de construir no Brasil" (Constantino, 2004, p.37).

O I Salão de Arquitetura Tropical, foi organizado pelos arquitetos Alcides da Rocha Miranda, João Lourenço da Silva e Ademar Portugal e contou com a colaboração do então jovem arquiteto Abelardo de Souza que, juntamente com Oscar Niemeyer, Carlos Leão, Luís Nunes, integrou uma das primeiras gerações de arquitetos modernos egressos da Escola Nacional de Belas Artes; condição que seria reforçada, por Abelardo de Souza, ao realizar o curso de Urbanismo da Universidade do Distrito Federal, em 1935, onde foi aluno de Lucio Costa, dentre outros mestres modernos (Constantino, 2004, p 44).

Neste período Lucio Costa, já demonstrava ser um grande admirador das ideias de Le Corbusier, ao defender sua orientação racionalista na arquitetura e contribuir, sob a coordenação daquele arquiteto, na elaboração de um Plano para a Cidade Universitária do Rio de Janeiro. Para atender às exigências da Universidade do Brasil (1936-1937), tal plano seria revisto pelo próprio Lucio Costa, cujo resultado final foi considerado "um testemunho não apenas da influência que sofreu das ideias expressas na Carta de Atenas (1933), como de seu método pessoal de projeto urbano - caracterizado por uma forte preferência por eixos de composição incisivamente expressos e regularidades volumétricas" (Leme, 199, p.502). 
No início de sua carreira profissional no Rio de Janeiro, Abelardo de Souza trabalhou com o Banco Lar Brasileiro e voltaria a trabalhar com esta mesma instituição em São Paulo, a partir dos anos 40, quando então transferiu sua residência para esta cidade, tornando-se um dos nomes mais presentes nos projetos realizados por esse grupo empreendedor.

Dentre os projetos realizados por Abelardo de Souza, para o Banco Lar Brasileiro destaca-se a implantação do Conjunto Jardim Ana Rosa, construído no bairro de Vila Mariana, na cidade de São Paulo. As razões de sua relevância serão descritas a seguir.

\section{Seção 2 - O Conjunto Jardim Ana Rosa}

O Conjunto Ana Rosa começou a ser construído em 1949, em uma área de mais de 55 mil m², que havia sido adquirida, pelo Banco Lar Brasileiro, dos proprietários de um tradicional estabelecimento de atendimento a crianças necessitadas- o Instituto Ana Rosa- cujo prédio principal localizava-se defronte ao Largo de mesmo nome. Nesta ocasião, o tecido urbano do entorno da área já se encontrava quase que totalmente consolidado.

De formato irregular e topografia bastante acidentada, a citada área possui um declive de 25 metros de seu ponto mais alto, o Largo Ana Rosa, ao seu ponto mais baixo, junto à Rua Paula Ney, apresentando também declive em suas laterais em direção a um vale, hoje totalmente edificado, ao longo do antigo leito do córrego Jurubatuba, além de um vale, de declives menos pronunciados e que abrigava uma nascente, no centro da gleba. Tais condicionantes topográficas poderiam ter tornado mais tímidas e convencionais as abordagens que foram efetivamente adotadas para implantação do conjunto em questão.

O projeto de urbanização, proposto pelo arquiteto Abelardo de Souza e implantado pelo Banco Lar Brasileiro, respeita as particularidades topográficas da área, trabalhada em uma série de terraços articulados acompanhando o declive do terreno e se organiza em torno de um eixo transversal de traçado sinuoso, a atual Rua Dr. José de Queirós Aranha. O arquiteto não implantou essa via numa das bordas dos limites da gleba, mas sim afastada dela, de modo a permitir a criação de lotes em cada um de seus lados e garantir assim unidade visual e organicidade ao empreendimento. Alinhou também a citada via à rua Rodrigues Alves - na época, importante eixo de ligação do bairro do Ibirapuera ao Largo Ana Rosa - de modo a permitir o fluxo contínuo do trânsito e, desse modo, integrar a nova via ao tecido viário existente e com ela articular o Bairro do Ibirapuera ao Bairro da Aclimação. Longitudinalmente o arquiteto garantiu a capilaridade do conjunto através do prolongamento das vias já existentes no seu entorno.

As condicionantes topográficas e as opções estruturantes da urbanização implicaram em um parcelamento constituído de quadras de dimensões diversas, suporte para a edificação e convivência de residências unifamiliares (geminadas ou isoladas no lote) e blocos multifamiliares com outras de uso misto. Duas áreas verdes integram o projeto, sendo que a maior delas situada ao longo da atual rua Nicolau de Souza Queirós, abriga uma Escola Municipal de Educação Infantil - EMEI. De fato, a urbanização proposta por Abelardo de Souza está organicamente integrada ao bairro passando quase despercebida, não fosse sua inigualável qualidade arquitetônica e ambiental 
Figura 5: Projeto inicial do loteamento realizado pelo Banco Hipotecário Lar Brasileiro, na década de 50. Observa-se, no lado esquerdo do desenho, o alinhamento da Rua 1, atual Dr. José de Queiros Aranha, com a rua Rodrigues Alves. Fonte: Fernanda Bárbara, (2004). evidenciada, de forma gradativa, ao se percorrer o traçado sinuoso e descendente da rua Dr. José de Queirós Aranha.

O projeto inicial do conjunto previa a construção de 300 apartamentos e lojas na proximidade do Largo Ana Rosa e 55 residências na Rua Dr. José de Queirós Aranha, além de 80 casas geminadas nas demais vias do empreendimento. Essa quantidade de moradias unifamiliares foi, no entanto, alterada durante o processo de construção dos referidos edifícios de uso misto e das residências lindeiras à Rua Dr. José de Queirós Aranha, com o surgimento de propostas que substituíam a construção de residências unifamiliares por edifícios multifamiliares nas quadras centrais do empreendimento. Não é possível precisar as razões que provocaram tais alterações de projeto - uma das causas prováveis seria a pressão por maior quantidade de unidades de moradia porém são indiscutíveis o significado e a contribuição das soluções de implantação e projetuais dos edifícios oriundos dessas transformações, para a arquitetura moderna paulista (Figura 5).

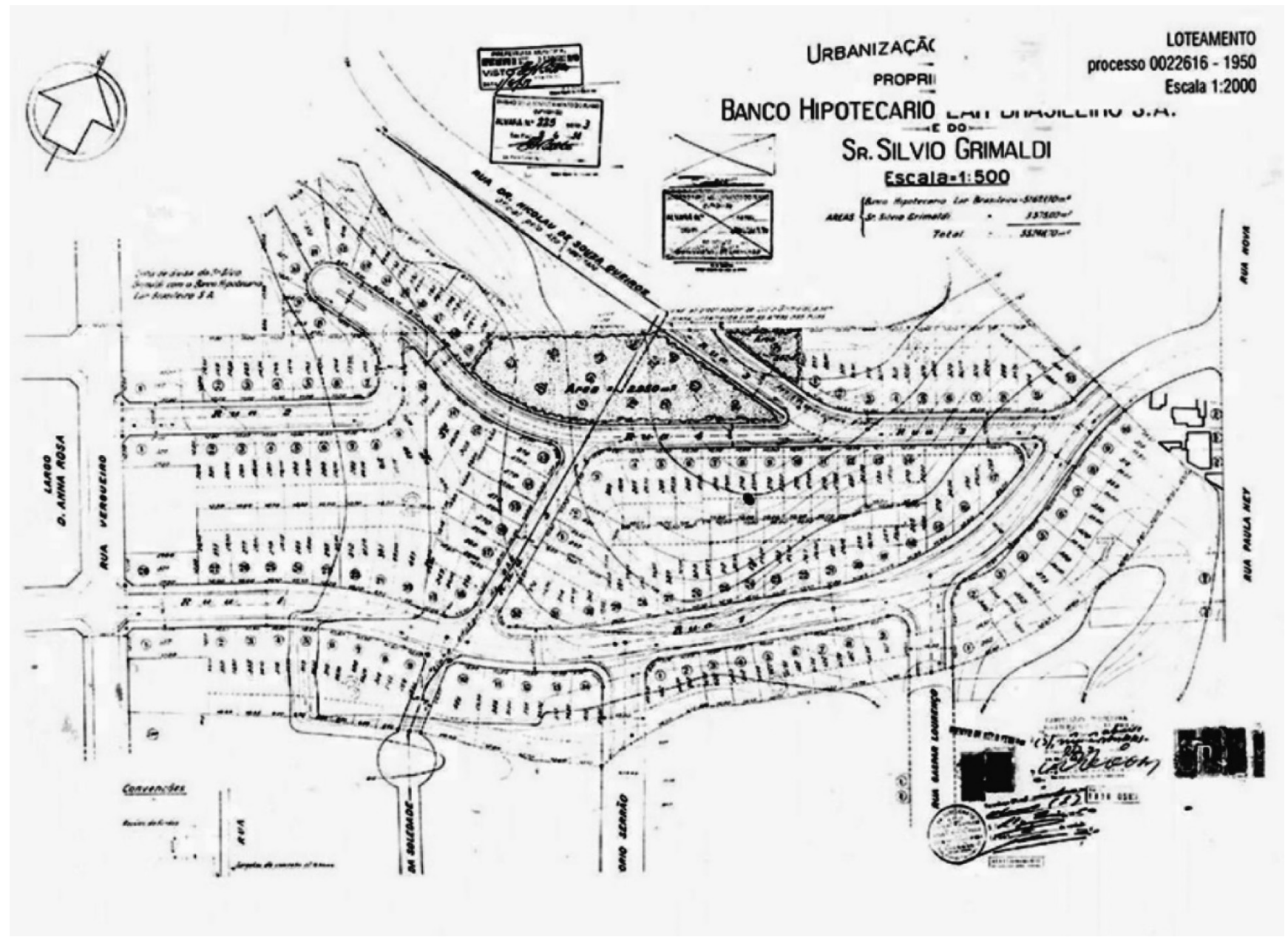




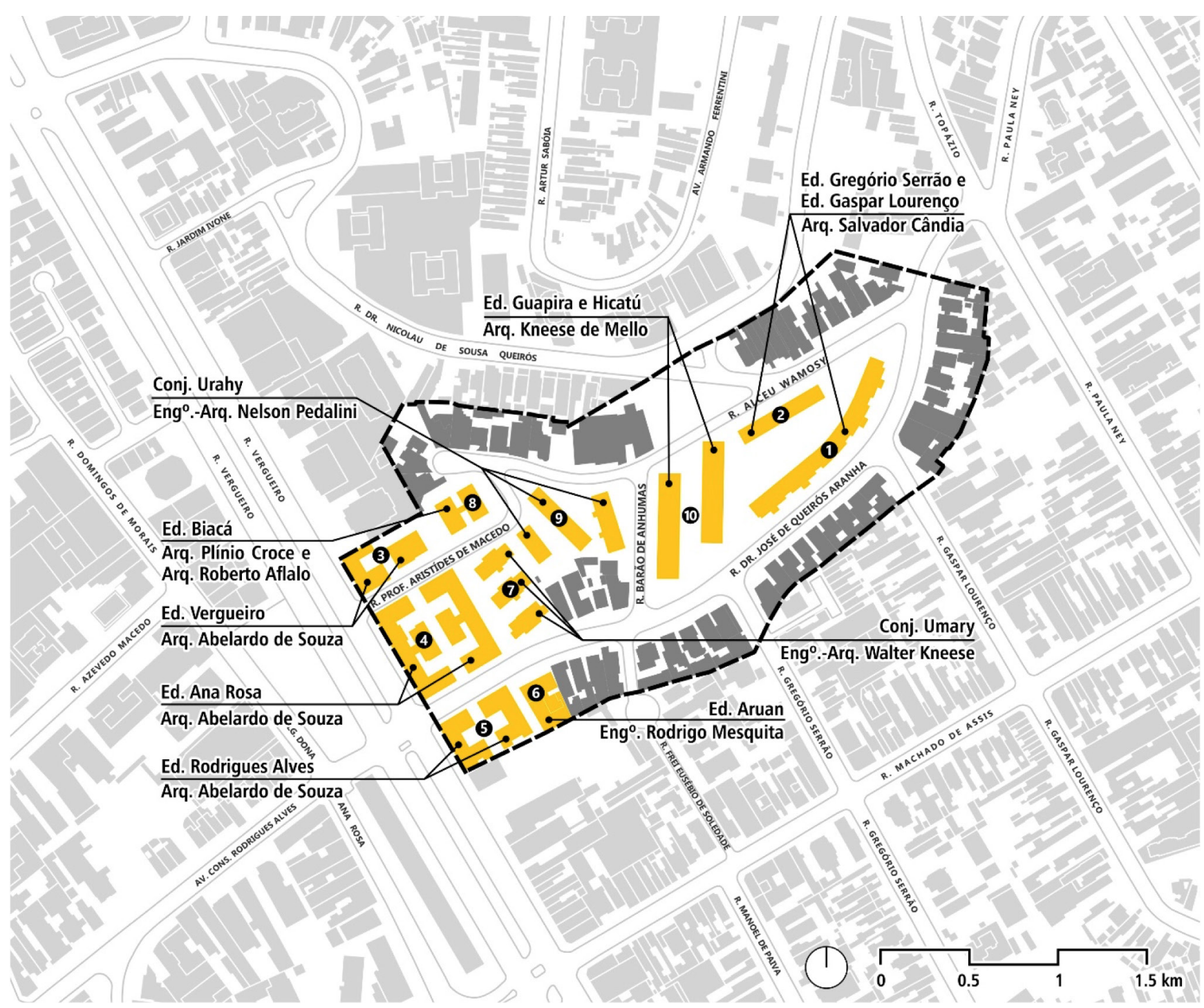

Figura 6: Projeto final: identificação dos autores dos edifícios multifamiliares. Fonte: Acervo autores (2017), a partir do Processo Público de Tombamento n²013-0.256.719-1.
As soluções projetuais das edificações que integram o Conjunto Ana Rosa são, à semelhança do Weissenhofsiedlung, individualizadas, ou seja, são obras autorais de diferentes arquitetos reunidos por Abelardo de Souza, que buscaram conciliar a solução formal particular de seus projetos ao padrão de renda pré-estabelecido de seu público potencial: os diferentes extratos da classe média que, impulsionados pelo desempenho da economia do país nos anos 50 e início dos 60 e pelas políticas de crédito implantadas por empreendedores como o Banco Hipotecário Lar Brasileiro, viam ampliadas as possibilidades de acesso à aquisição da casa própria.

A equipe de profissionais envolvidos nos projetos, foi composta pelos seguintes arquitetos e engenheiros-arquitetos, que se tornariam posteriormente expoentes da arquitetura moderna brasileira: o próprio Abelardo de Souza; Salvador Candia; Plinio Croce; Roberto Aflalo; Eduardo Kneese de Melo; Walter Kneese e Nelson Pedalini (Figura 6). Também Eduardo Corona teria integrado essa equipe (seria o autor do projeto do edifício Uraí, segundo informação não registrada de arquitetos já falecidos); pela documentação levantada não foi possível confirmar essa hipótese, bastante plausível, pela qualidade do projeto arquitetônico do referido edifício. 
As plantas dos edifícios multifamiliares e de uso misto apresentam soluções racionais, com dimensionamentos de espaços e tipos de ambientes dentro das práticas da época - como por exemplo "dependências de empregada" para unidades habitacionais de 01, 02 e 03 dormitórios - com áreas molhadas agrupadas e materiais de acabamento econômicos. São edifícios que apresentam estruturas funcionais em concreto armado, em geral aparentes ou evidenciadas, sem a presença de elevadores e com no máximo 5 pavimentos - exceção feita aos edifícios Hicatú e Guapira de Walter Kneese de Melo, que contam com 6 pavimentos.

Predominam na maioria das edificações as soluções de coberturas planas, ou do tipo asa de borboleta ou, ainda, de uma água, exceção feita às casas unifamiliares da rua Dr. José Queiroz Aranha, com duas águas e algumas poucas unidades com quatro águas na última quadra do conjunto, próximo à rua Paula Ney.

O processo de execução do Conjunto Ana Rosa iniciou-se com a realização de obras para adequação do terreno e para a instalação de toda a infraestrutura necessária água, esgoto, gás encanado, luz - além da construção e pavimentação das novas vias segundo o traçado proposto por Abelardo de Souza, os quais foram executados "às expensas do Banco Lar Brasileiro", segundo registros presentes na Revista Acrópole (Gruenwald,1951, p.56).

As primeiras edificações começaram a ser erigidas entre os anos 1949 a 1952. Tratamse dos edifícios de uso misto - comércio no térreo e moradia nos demais andares - localizados nas esquinas da rua Vergueiro com Rua Dr. José de Queiroz Aranha (Edifícios Ana Rosa e Rodrigues Alves) e com a rua Prof. Aristides de Macedo (Edifício Vergueiro), além das residências unifamiliares no lado par da R. Dr. José de Queiroz Aranha e rua Alceu Wamosy (casas geminadas) e também na rua Barão de Anhumas, incluindo alguns lotes do lado ímpar da rua Dr. José de Queiroz Aranha, no final da primeira quadra do conjunto, desse lado ímpar. Nessa etapa foram construídas cerca de 40 casas isoladas e 14 casas geminadas.

Os edifícios Ana Rosa, Rodrigues Alves e Vergueiro foram projetados pelo arquiteto Abelardo de Souza. O Ana Rosa se constitui de dois blocos, de térreo mais dois pavimentos, com coberturas em forma de asa de borboleta e estão articulados por um jardim com acessos pela rua Dr. José de Queiroz Aranha. As faces voltadas para esta rua e para a rua Vergueiro têm o térreo inteiramente ocupado por estabelecimentos comerciais. O edifício Rodrigues Alves repete as soluções arquitetônicas e de implantação adotadas no Ana Rosa, embora apresente menor testada e menor área do lote. O edifício Vergueiro, implantado simetricamente ao edifício Ana Rosa, adota as mesmas soluções arquitetônicas dos outros dois à exceção da orientação da cobertura - em forma de asa de borboleta - que, no caso, encontra-se voltada para a rua Vergueiro e não para a rua lateral, como no caso dos outros dois.

Nenhuma construção foi feita inicialmente na grande quadra triangular situada entre as ruas Dr. José de Queiroz Aranha, Barão de Anhumas e Alceu Wamosy; como dito anteriormente, a previsão inicial era de que essa quadra fosse ocupada por residências unifamiliares, parte delas geminadas e parte isoladas no lote. Também os terrenos nos quais foram construídos os edifícios Biacá, Uray, Umary e Aruan (construídos entre 1951 e 1954) tinham, inicialmente, a previsão de serem ocupados por residências unifamiliares. 
O Edifício Biacá foi projetado pelos arquitetos Plínio Croce e Roberto Aflalo em 1951, é composto por dois blocos articulados em torno da área comum de circulação vertical envidraçada e circundada por jardins. As fachadas têm refinado tratamento em caixilharia de vidro e painéis de madeira evidenciando a modulação dos vãos. Garagens individuais no pavimento inferior.

O edifício Uray foi projetado pelo engenheiro-arquiteto Nelson Pedalini. É composto por 3 blocos de diferentes tamanhos, implantados sem seguir orientações de esquinas ou do traçado das ruas que fazem limite ao lote atendo-se apenas à topografia do terreno e à orientação de melhor insolação. A composição das fachadas ressalta as linhas horizontais representadas pelas marcações das lajes dos pisos interrompidas pelos blocos de circulação vertical que se destacam com sua caixilharia modulada. Parte dos térreos livres, são ocupados por garagens.

O edifício Umary foi projetado pelo engenheiro-arquiteto Walter Kneese, sendo composto por 3 blocos sucessivos englobando térreo mais 2 pavimentos considerando a implantação pelo lado da rua Dr. José de Queiroz Aranha; aproveitando a declividade do terreno e a cota pela rua Prof. Aristides de Macedo é introduzido um pavimento inferior nos 3 blocos, sob pilotis, que é ocupado por estacionamento para veículos. Em cada um dos edifícios do condomínio a fachada modulada é centrada pelo bloco de circulação vertical encimado por caixa d'água integrada num único volume o que dá destaque a esse bloco na composição da fachada.

Sobre o edifício Aruan documentos existentes no arquivo da Prefeitura Municipal de São Paulo, apontam ter sido o engenheiro Rodrigo Odilon Guedes Mesquita, o construtor do edifício, bem como o autor do projeto e o responsável pela obra. No entanto em alguns depoimentos verbais de arquitetos que atuaram nesse período, o projeto é atribuído ao arquiteto Eduardo Corona que, no início dos anos 1950, trabalhava em estreita colaboração com o arquiteto Abelardo de Souza. É composto de térreo mais dois pavimentos e possui movimentado tratamento formal na fachada do térreo com envasaduras que se projetam em diagonal com relação aos pavimentos superiores.

No tocante a grande quadra triangular, o engenheiro-arquiteto Eduardo Kneese de Mello propôs, em 1951, a construção, de 5 blocos laminares, implantados sequencialmente, com faces paralelas à rua Barão de Anhumas e diagonalmente com relação à rua Dr. José de Queiroz Aranha. Dessa proposta, apenas dois desses blocos foram construídos, em 1952: o Hicatú e o Guapira.

Tratam-se de edifícios de 6 pavimentos, com coberturas em forma de asa de borboleta implantados em nível com a Rua Alceu Wamosy, em uma cota aproximadamente 10 metros abaixo da cota da rua Dr. José de Queirós Aranha. A planta das unidades obedece aos princípios modernistas e incorpora um pequeno terraço voltado às áreas verdes que ladeiam os blocos São apartamentos tipo duplex, de dois dormitórios, com grandes caixilhos em madeira e vidro e painéis de cobogós nas áreas da cozinha e de serviço, que compõem as fachadas, idênticas em ambas as edificações, de rigorosa composição geométrica (Figura 7). 
Figura 7: Fachada lateral do Edifício Hicatú e Guapira e sistem).a de passarelas e escada de mesma solução para ambos os edifícios. Fonte: Acervo autores (2017).
A opção do arquiteto por apartamentos duplex conjuga-se à solução proposta para os acessos principais aos dois edifícios, junto a Rua Dr. José de Queirós Aranha: 2 conjuntos de 2 passarelas com entradas independentes.

Da passarela situada no nível mais baixo existe uma escada em caracol que conecta com os pavimentos inferiores. A associação dessas passarelas e escada permite que os moradores acessarem suas unidades sem ter para isso que vencer mais do que 02 pavimentos. Existe um outro acesso pela rua Alceu Wamosy, a partir do nível dos apartamentos da cota mais baixa do edifício. Entre os dois blocos uma densa massa vegetal cria o isolamento visual.

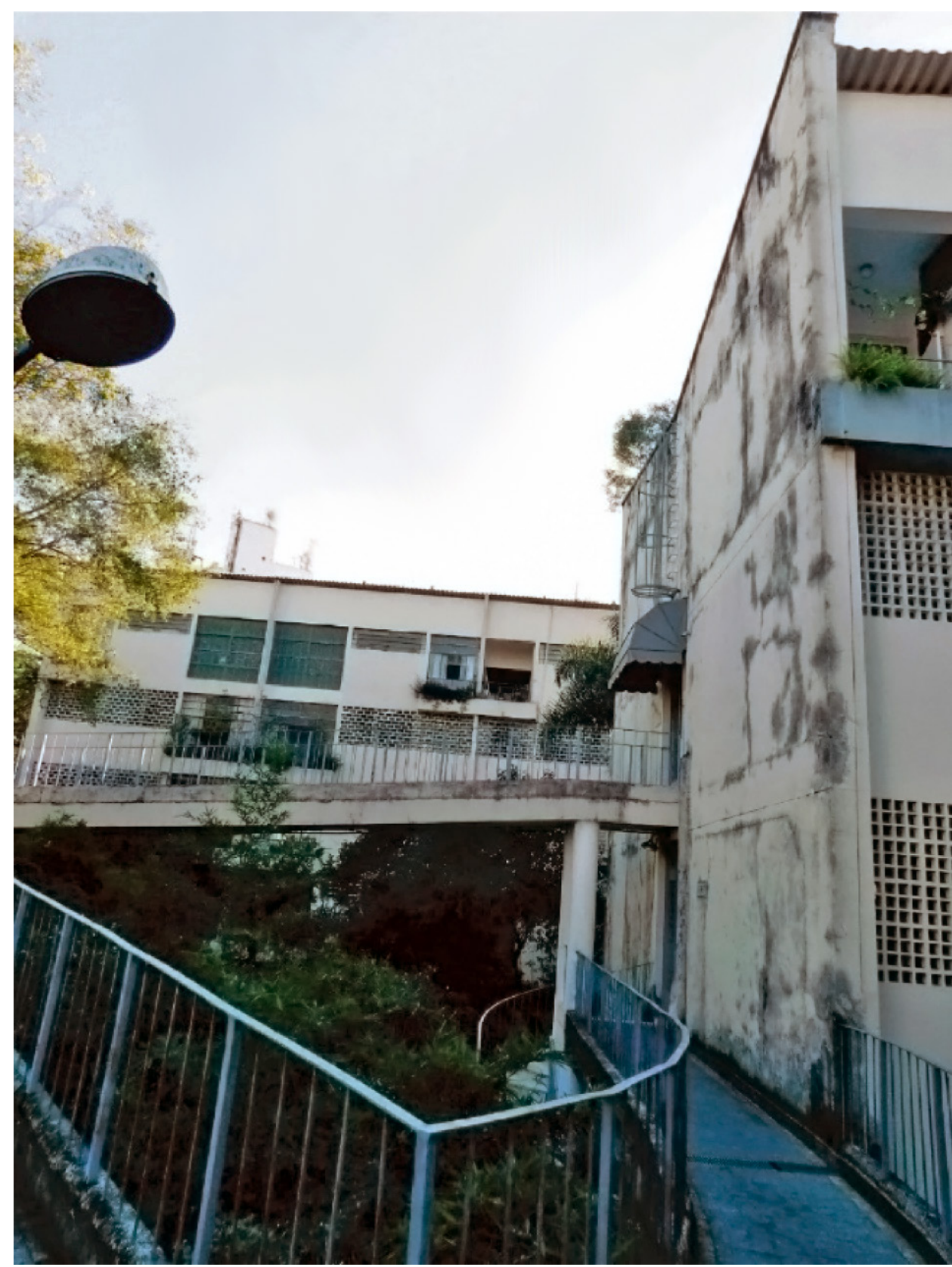




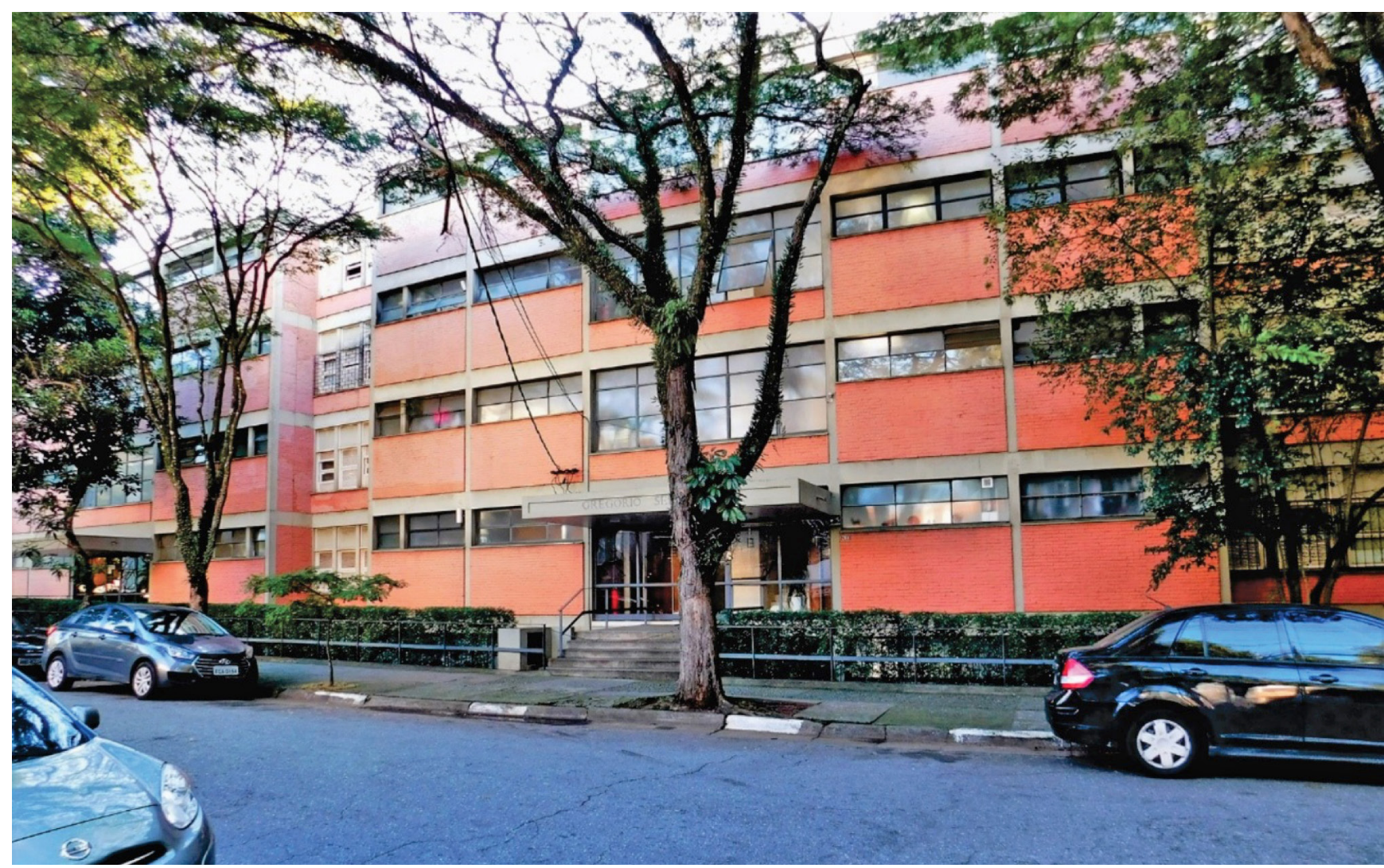

Figura 8: Fachada do conjunto Gregório Serrão, voltada para a Rua Dr. José de Queirós Aranha. Fonte: Acervo autores (2017).
Na segunda metade dos anos 50 foi complementada a ocupação do restante da quadra com a construção de dois edifícios, projetados pelo arquiteto Salvador Candia.

Destaca-se o conjunto Gregório Serrão, o maior deles, composto por 05 blocos geminados de 5 pavimentos, alinhados ao longo do trecho sinuoso da rua Dr. José de Queiroz Aranha, o que Ihe conferiu a forma de uma extensa lâmina curva voltada, no tocante à insolação para a orientação sudeste-noroeste. Cada um dos 5 blocos possui apartamentos de 2 e 3 dormitórios, agrupados 2 a 2 por andar e sua cobertura é em laje plana (Figura 8).

Os acessos principais aos 05 blocos se dão por meio de passarelas suspensas sobre um recorte intermediário realizado no terreno para mitigar o declive acentuado da topografia original e, desta forma, permitir a construção de um pavimento com apartamentos abaixo do nível da rua. Para essa face (predominantemente sudeste) estão voltadas a cozinha, área de serviço e um dos quartos.

Os halls das entradas principais de cada bloco receberam vedação integral em vidros sustentados por leve caixilharia em ferro, permitindo a integração visual entre interior e exterior do edifício que, juntamente com as janelas em fita e com o esqueleto estrutural em concreto aparente conferem a esta fachada uma composição harmônica e ritmada. 
Figura 9: Fachada posterior do conjunto Gregório Serrão, destaque para o brise-soleil. Fonte: Acervo autores (2017).
A face posterior do conjunto, para onde estão voltados os demais quartos e salas, também possui janelas em fita, sendo protegida por brise-soleil composto por grelha de concreto de superfície côncava, recoberta por pastilhas, de grande efeito plástico (Figura 9).

Nesta face, o edifício tem seu pavimento inferior assentado na cota mais baixa do terreno, onde foram alocadas as garagens individuais e os acessos secundários aos blocos, sendo todo o conjunto voltado, nessa cota, para uma área livre composta por playground, áreas de circulação e generosas áreas arborizadas, que também promovem a articulação com o outro edifício projetado por Salvador Candia, o Condomínio Gaspar Lourenço, que abriga apartamentos de 1 e 2 dormitórios e com seus outros vizinhos de quadra: os edifícios Hicatú e Guapira.

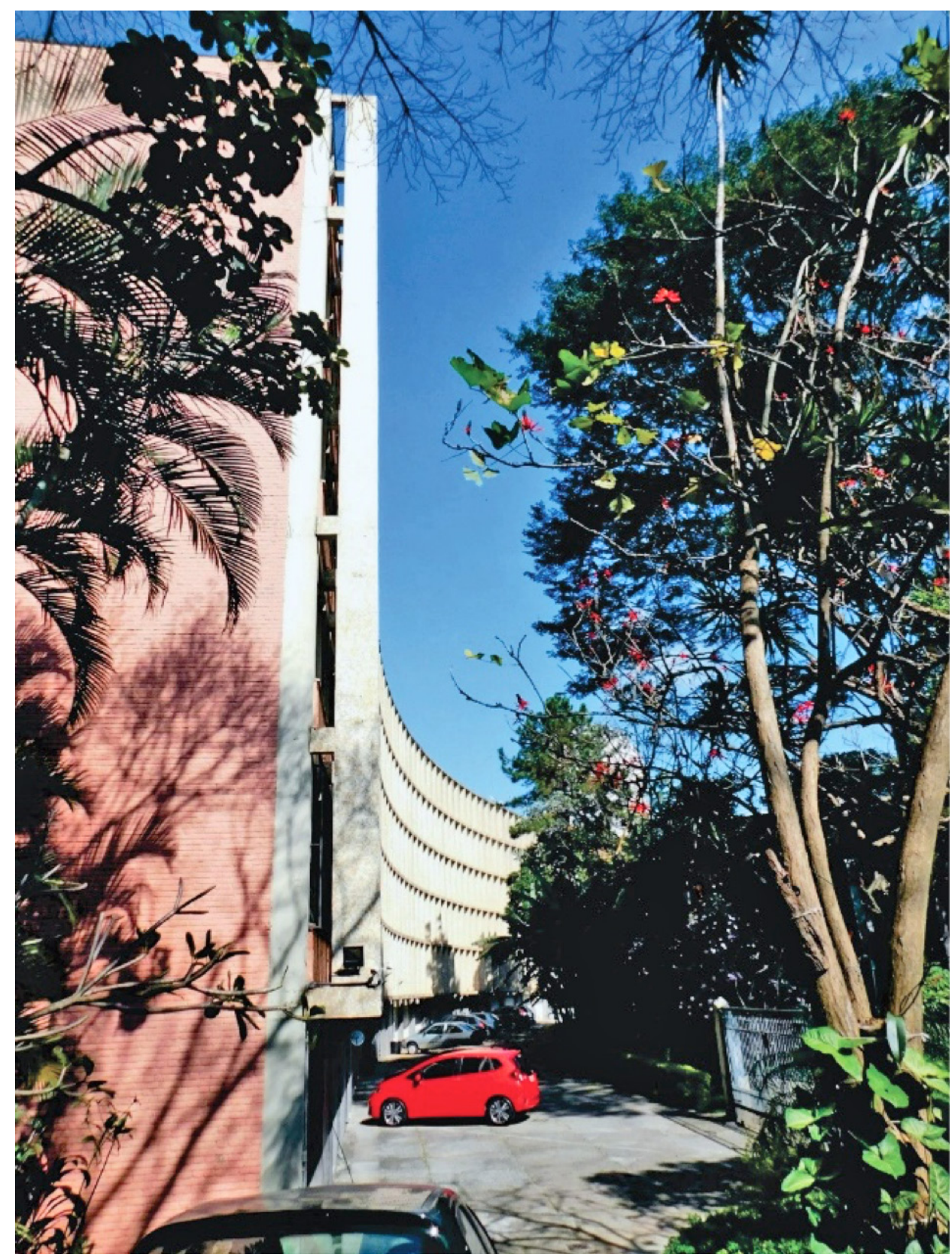


Nenhum dos edifícios do conjunto é servido por elevadores o que foi possibilitado pela baixa altura dos mesmos e pela forma de implantação na topografia do terreno, que permitiu não subir mais do que três pavimentos, a partir do acesso principal, para se alcançar o último andar.

Internamente, nas faces de cada apartamento voltadas para o pátio interno, as janelas tipo guilhotina com caixilhos de madeira e vidro estão integradas a painéis modulados de madeira que recobrem todos os vãos dos cômodos (salas e quartos), resultando em refinada solução plástica. Os caixilhos da cozinha e área de serviço são de ferro fundido e assentados ao longo das extensões dos vãos que percorrem a fachada desses ambientes. De fato, a ventilação cruzada em todos os cômodos é característica marcante do projeto.

As soluções urbanísticas, tipológicas e construtivas presentes no Jardim Ana Rosa, conformam, em seu conjunto, um significativo acervo de arquitetura moderna voltada para a classe média que, conjugado à escala do empreendimento e a implantação cuidadosa com a topografia e malha urbana existentes, revelam um projeto urbano de indiscutível qualidade paisagística e ambiental.

\section{Considerações finais}

Na literatura pesquisada, não se encontrou demonstrações de influências diretas das experiências vivenciadas no Weissenhofsiedlung, no projeto do conjunto Jardim Ana Rosa, no entanto, não se pode desconsiderar o aspecto seminal da experiência alemã nas formas de se pensar novas possibilidades de morar traduzidas, nos projetos arquitetônicos, no emprego de materiais construtivos industrializados e nas formas livres de implantação das edificações no terreno.

De fato, a observação mais atenta das duas experiências permite constatar que, embora tenham modelos de produção distintos entre si: o primeiro é resultado da associação entre o Werkbund com Departamento de Obras de Stuttgart e o segundo de um empreendimento imobiliário, ambos mesclam harmoniosamente residências unifamiliares isoladas ou agrupadas no lote com blocos multifamiliares verticalizados, voltados ao bem morar da classe média. Apresentam soluções espaciais comuns, onde o tipo de divisão parcelaria da gleba, os tipos de quadras, de lotes, de vias e áreas verdes, fogem aos padrões óbvios

Outro aspecto, de relevante importância, que se evidencia entre os dois projetos urbanos, foi a de reunir vários arquitetos comprometidos com os princípios e práticas da arquitetura e urbanismo modernos e a quem foi dada a possibilidade de realizar, com certa liberdade, projetos autorais e inovadores, mesmo considerando a origem comercial do Conjunto Jardim Ana Rosa, em que seu financiador, o Banco Lar Brasileiro, possivelmente entendia tal diversidade de arquitetos e de projetos "mais propriamente como um atrativo de mercado que por uma preocupação com boa arquitetura" (Constantino, 2004, p.60)

A implantação do Weissenhofsiedlung, bem como o do Conjunto Jardim Ana Rosa, seguiu, frente as características topográficas similares de ambas as glebas, formas não convencionais de urbanização. Em ambos os casos se respeitaram as particularidades 

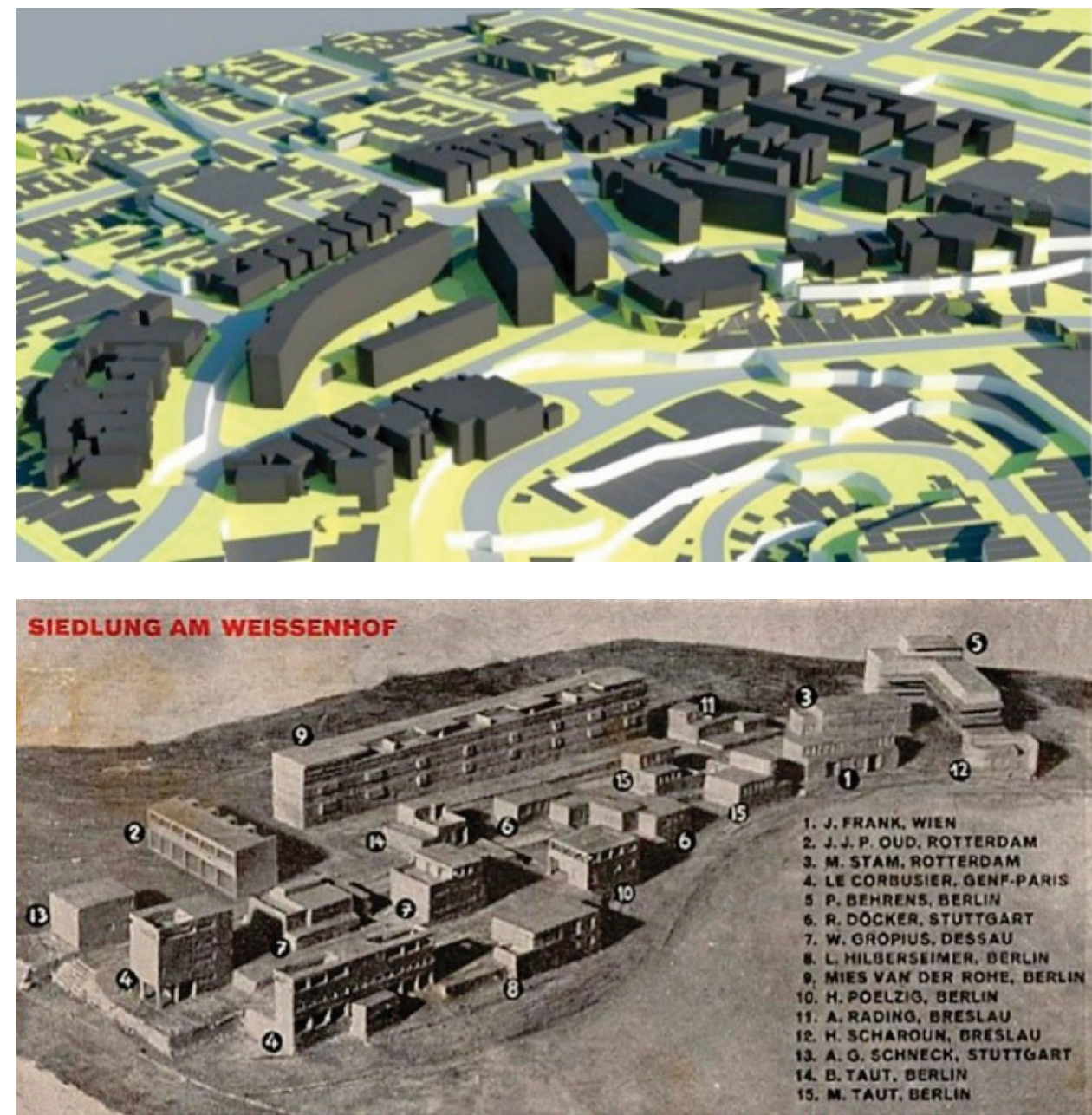

Figura 10: topo - reprodução da maquete do Conjunto Jardim Ana Rosa - Processo Tombamento $n^{\circ}$ 2013-0.256.719-1; embaixo reprodução da maquete do Weissenhofsiedlung. Fonte: Sommer (2007, p.20). topográficas da área, que foram trabalhadas em uma série de terraços articulados e edificações, predominantemente de baixo gabarito, implantadas sem grades ou muros, segundo a melhor orientação para insolação e aeração, sem se prender à orientação dada pelas esquinas, e permeadas por áreas verdes, de modo a produzir uma paisagem urbana de qualidade ambiental marcada por linhas horizontais. (Figura 10).

No entanto, ao se debruçar mais atentamente à implantação em ambos os projetos, observa-se que, no caso do Weissenhofsiedlung, Mies van de Rohe estruturou seu projeto através de uma hierarquia de espaços públicos, que não se observa no caso do Conjunto Ana Rosa.

No caso alemão, o perímetro do conjunto é delimitado por vias secundárias utilizadas por veículos motorizados e pedestres as quais se conectam a uma via principal que conduz ao centro de Stuttgart. O acesso e a saída ao interior do conjunto por veículos motorizados se dá apenas por duas vias paralelas não concebidas para possibilitar que os veículos cruzassem o terreno, prerrogativa essa dada apenas ao pedestre, através da continuidade dessas vias por escadas, que vencem a topografia acidentada do local. 
Essa opção de Mies van der Rohe, garantiu aos moradores certa privacidade de acesso e de uso dos espaços comuns no interior do conjunto, o que não se observa com relação à estrutura viária concebida por Abelardo de Souza para o Conjunto Ana Rosa, estruturado em torno de um eixo transversal de traçado sinuoso, a Rua Dr. José de Queirós Aranha. Apenas na área da quadra maior, onde estão os projetos de Salvador Candia e Eduardo Kneese de Mello encontra-se evidenciada essa possibilidade de interligação entre os blocos, possibilitada pela grande área central comum, reservada a um trânsito de pedestres (embora também prevista para ser usada como acesso às garagens).

De fato, esse espaço comum, sem expressar a divisão dos lotes de cada empreendimento isolado, nos remete a ideia expressa no CIAM I, de adoção de uma política de terras coletiva como forma de se evitar a divisão caótica de terras na cidade. Sem dúvida uma possibilidade cada vez mais distante nos modos de produção capitalista de nossas cidades.

Embora os projetos autorais de arquitetura do Conjunto Jardim Ana Rosa guardem relativa distância com relação à algumas soluções arquitetônicas adotadas no Weissenhofsiedlung, em especial pelo uso que este último fez de coberturas com terraço e jardins, lavanderias comunitárias, sistema estrutural em aço e tipologias flexíveis nas unidades habitacionais, por outro lado se aproximam ao lançarem mão de pelo menos três dos cinco pontos definidos por Le Corbusier e Pierre Jeanneret como essenciais para a Nova Arquitetura, quais sejam, o emprego de pilotis, o uso de janelas em fita e o tratamento livre das fachadas pelo emprego de sistema estrutural independente.

O caráter expositivo e disseminador de um novo modo de pensar a arquitetura e as cidades presentes no Weissenhofsiedlung e a origem comercial do Conjunto Jardim Ana Rosa, que impuseram condicionantes diversas para os envolvidos em uma e outra experiência e exigiram soluções adequadas para cada uma de suas necessidades, conjugados ao distanciamento no tempo entre as duas experiências e a efervescência, nesse período e em tempos posteriores, dos debates em torno dos caminhos da arquitetura moderna, não tiraram o interesse da discussão das similaridades e dos contrastes existentes entre ambos.

\section{Bruno Taut (1880-1938)}

Um dos primeiros arquitetos associados ao Deutscher Werkbund, é o autor do Pavilhão de Cristal, uma de suas obras mais conhecidas; essa obra integrou a $1^{\text {a }}$ Mostra do Deutscher Werkbund, em 1914, na cidade de Colonia (Alemanha).

Em Berlim, já trabalhando com urbanizações e habitações voltadas para trabalhadores, tornou-se diretor de construção da GEHAG, maior sociedade de edificações de Berlim, quando então realiza as suas urbanizações mais conhecidas: o Hufeisensiedlung no bairro de Britz (1925-1929) e o Onkel Toms Hütte (1926-1931). Por conta de perseguições politicas sai da Alemanha em 1933, morrendo em Istambul, em 1938.

\section{Victor Bourgeois (1897-1962)}

Estudou na Academie Royale des Beaux Arts, Bruxelas. Considerado o maior arquiteto modernista da Bélgica, fundou diversas revistas de arquitetura e arte. Participou do I 
CIAM, do qual foi um dos fundadores. Projetou e construiu inúmeras obras em Bruxelas e foi um dos autores do Pavilhão da Bélgica na Feira Mundial de Nova lorque, de 1939. Único arquiteto belga a integrar a equipe de arquitetos do Weissenhofsiedlung; integrou a equipe a convite da municipalidade de Stuttgart.

\section{Salvador Roque Augusto Candia (1924-1991)}

Nasceu em Campo Grande, mudando-se para São Paulo em 1933, onde morou até o final de sua vida em 1991. Formou-se arquiteto em 1948 pela Faculdade de Arquitetura Mackenzie. Dentre os colegas presentes em seu processo de formação profissional encontravam-se Plinio Croce, Roberto Aflalo, Carlos Milan, Miguel Forte, Carlos Lemos dentre outros. No final dos anos 40 edita, juntamente com Jorge Wilheim, Carlos Milan, Roberto Carvalho Franco, Paola Tagliacozzo e Sydnei da Fonseca, a Revista Pilotis, sobre as artes modernas. Neste período estagiou no escritório de Rino Levi.

Em 1947 entra em contato com a obra de Mies van der Rohe que exerceria uma forte influência em seu trabalho posterior, o que o levaria a se auto definir como miesiano. Em 1948, integra juntamente com Eduardo Kneese de Melo, Rino Levi, Gregori Warchavschik, Luis Saia, Carlos Cascaldi, Jacob Ruchti, dentre outros, a equipe que cria o Museu de Arte Moderna -MAM. Em 1951 entra em contato com Siegfried Giedion por ocasião da $1^{a}$ Bienal Internacional em São Paulo. Em 1957 recebe juntamente com Plinio Croce e Roberto Aflalo o primeiro prêmio de Habitações Coletivas, pelo projeto do edifício João Ramalho, no bairro das Perdizes/SP.

Nos anos 50 participa de vários trabalhos para o Banco Hipotecário Lar Brasileiro, entre esses os projetos para os conjuntos Gregório Serrão e Gaspar Lourenço do Jardim Ana Rosa. Em 1954 realiza com Plinio Croce, Roberto Aflalo e Carlos Milan, projeto para Instituto Pesquisas Tecnológicas-IPT fortemente influenciado pelo projeto para o Campus do IIT Chicago de Mies van der Rohe. Entre 1959 projeta, com Giancarlo Gasperini, a Galeria Metrópole. Nos anos 60 articula um grupo de arquitetos para participar do Plano Diretor de São Paulo, o que acaba não se realizando. Durante os 40 anos de sua vida profissional estabeleceu vínculos com inúmeros arquitetos. (Informações baseadas na tese de doutorado de Ferroni, 2008)

\section{Eduardo Kneese de Melo (1906-1994)}

Formado engenheiro-arquiteto em 1931, pela Faculdade de Arquitetura Mackenzie, Eduardo Kneese de Melo só aderiu às premissas do Movimento Moderno em 1940, quando participa do $\mathrm{V}$ Congresso Pan-Americano de Arquitetos em Montevidéu. Somente nesta oportunidade tomaria consciência de que sua opção anterior, pela arquitetura eclética, era um equívoco. Sua opção posterior pelo modernismo não foi apenas formal, mas no sentido de repensar o alcance social da obra de arquitetura.

Engajou-se na proposta de instalar em São Paulo uma sede regional do IAB, juntamente com Artigas, Rino Levi e outros arquitetos e tornou-se seu primeiro presidente (1943). Em 1948 participa, juntamente com um grupo de arquitetos e intelectuais, da criação do Museu de Arte Moderna de São Paulo-MAM. 
Atuante como arquiteto e professor durante toda sua vida, foi autor de um número significativo de obras marcantes, como a sede do Instituto de Aposentadorias e Pensões dos Industriários-IAPI/SP em1947, do Conjunto para Estudantes da USP-CRUSP, em 1961; do edifício da Faculdade de Arquitetura e Urbanismo Farias Brito da Universidade de Guarulhos, em 1981; participou da concepção do Parque Ibirapuera, na equipe de Niemeyer; como arquiteto da Novacap participou da construção de Brasília, durante 2 anos. São também de sua autoria um número significativo de edifícios residenciais, como os edifícios Hicatú e Guapira do Conjunto Jardim Ana Rosa, em 1952. (Informações baseadas parcialmente no artigo de Dalva Thomaz, 1993).

\section{Referências bibliográficas}

AFLALO, Roberto; CROCE, Plinio. Prédios de Apartamentos. Revista Acrópole, n 188, p. 351 353, Ano 16, Dez. 1953. Disponível em: <http://www.acropole.fau.usp.br/>. Acesso em 25/05/2017.

ABASCAL, Eunice Helena; PIMENTA, Celio. Arquitetura Mackenzie e o Jardim Ana Rosa em São Paulo. Arquitextos, São Paulo, ano 10, n 114.03, Vitruvius, nov. 2009. Disponível em: <http://www.vitruvius.com.br/revistas/read/arquitextos/>. Acesso em 25/05/2017.

BÁRBARA, Fernanda. O conjunto Ana Rosa e o edifício Copan: contexto e análise de dois projetos realizados em São Paulo na década de 1950. 2004. Dissertação (Mestrado). Faculdade de Arquitetura e Urbanismo da Universidade de São Paulo, São Paulo, 2004.

BEDOLINI, Alessandra Castelo B. Banco Hipotecário Lar Brasileiro: análise das realizações no Estado de São Paulo 1941-1965. 2014. Dissertação (Mestrado). Faculdade de Arquitetura e Urbanismo da Universidade São Paulo, São Paulo, 2014.

BENEVOLO, Leonardo. História da Arquitetura Moderna. São Paulo: Perspectiva, 1976.

CABRAL, Cláudia Piantá Costa. Do Weissenhofsiedlung ao Hansaviertel. A arquitetura moderna e a cidade pensadas desde a habitação. Resenhas Online, São Paulo, ano 10, n.117.02, Vitruvius, set. 2011. Disponível em <http://www.vitruvius.com.br/revistas/read/resenhasonline/10.117/4025>.

CONSTANTINO, Regina A. A Obra de Abelardo de Souza. 2004. Dissertação (Mestrado). Faculdade de Arquitetura e Urbanismo da Universidade São Paulo, São Paulo, 2004

ECKSTEIN, Hans. Finding The Norm And Standrd, Construction for the Existenzminimum: the Werkbund and news taskes in the social state. In: BURCHARDT, Lucius; The Werkbund: studies in the history and ideology of the Deutscher Werkbund 1907-1933. London: The Design Council, 1980, p. 81 a 84.

ESKINAZI, M.O. Arquitetura e Cidade em Exposição: As Exposições de Arquitetura e as Bases do Projeto Moderno na Alemanha. In: Anais $8^{\circ}$ Seminário DOCOMOMO Brasil. Rio de Janeiro, 2009.

FERRONI, Eduardo R. Aproximações sobre a Obra de Salvador Candia. Dissertação (Mestrado). Faculdade de Arquitetura e Urbanismo da Universidade São Paulo. São Paulo, 2008

FORTE, Fernando. Marcas do Cotidiano Paulista. In: Revista AU-Arquitetura e Urbanismo. Ano 25, nº 190, p. 59-63, São Paulo: Jan.2010.

FRAMPTON, Kenneth. História Critica da Arquitetura Moderna. São Paulo: Gustavo Gilli, 1993.

GRUENWALD, Max. Banco Hipotecário Lar Brasileiro, 26 anos servindo o público. Revista Acrópole, n 158, p. 56-68, Ano 14, Jun 1951. Disponível em: <http://www.acropole.fau.usp. br/>. Acesso em 25/05/2017.

JOEDICKE, Jürgen. Weissenhofsiedlung. Stuttgart, Kraemerverlag, 2016. 
KNEESE, Walter; PEDALINI, Nelson. Prédios de Apartamentos. Revista Acrópole, n 197, p. 226-228, Ano 17. Fev. 1955. Disponível em: <http://www.acropole.fau.usp.br/>. Acesso em 25/05/2017.

LEME, Maria Cristina da Silva (coord.). Urbanismo no Brasil 1895-1965. São Paulo, Studio Nobel; FAUUSP; FUPAM, 1999

MELLO, Eduardo Kneese. Conjunto Residencial "Jardim Ana Rosa". Revista Acrópole, n 182, p. 74-75, Ano 16, Jun. 1953. Disponível em: <http://www.acropole.fau.usp.br/>. Acesso em 25/05/2017.

MUNFORD, Eric. The CIAM Discourse on Urbanism, 1928-1960. Massachusetts, Mit Press, 2002.

PETSCH, Joachim. The Deutscher Werkbund From 1907 To 1933 And The Movements For The "Reform Of Life And Culture". In: BURCHARDT, Lucius; The Werkbund: studies in the history and ideology of the Deutscher Werkbund 1907-1933. London: The Design Council, 1980; p.85 a 93

POLETO, Salua K.M. Referências Européias de Arquitetura e Urbanismo nas Origens da Produção de Habitação de Interesse Social no Brasil (1930-1964). 2014. Tese (Doutorado). Departamento de Arquitetura da Escola de Engenharia São Carlos da Universidade São Paulo, 2014.

POSENER, Julius. Between Art And Industry The Deutscher Werkbund. In: BURCHARDT, Lucius; The Werkbund: studies in the history and ideology of the Deutscher Werkbund 1907-1933. London: The Design Council, 1980; p. 07 a 15.

SOMMER, Kees. The CIAM and Cornelis van Eesteren, 1928-1960. Rotterdam: NAI Publishers, 2007, p.20.

SCHWARTZ, Frederic J. As Novas Formas da Cultura na Era Industrial. In Deutscher Werkbund: 100 anos de arquitetura e design na Alemanha (catálogo de exposição). São Paulo: Centro Cultural São Paulo, 2014

THOMAZ, Dalva. As Razões de Ontem, Hoje e Sempre. In: Revista AU-Arquitetura e Urbanismo. Ano 8, n 45, p. 79-88, São Paulo: Dez 1992- Jan.1993.

WINFRIED, Brenne. Bruno Taut- Master of Colorful Architecture in Berlin. Berlim: Braun Publishing, 2013. 